\title{
San Andreas Fault Zone Mineralogy, Geochemistry, and Physical Properties from SAFOD Cuttings and Core
}

\author{
by John G. Solum, Stephen Hickman, David A. Lockner, Sheryl Tembe, Jim P. Evans, \\ Sarah D. Draper, D.C. Barton, David L. Kirschner, Judith S. Chester, \\ Frederick M. Chester, Ben A. van der Pluijm, Anja M. Schleicher, Diane E. Moore, \\ Carolyn Morrow, Kelly Bradbury, Wendy M. Calvin, and Teng-fong Wong
} doi:10.2204/iodp.sd.s01.34.2007

\section{Introduction}

The San Andreas Fault Observatory at Depth (SAFOD), drilled near the town of Parkfield, California (Fig. 1) (Hickman et al., 2004) as part of the U.S. National Science Foundation's EarthScope Project (see http://www.earthscope.org), provides a continuous set of samples through the active San Andreas Fault (SAF) zone. These samples can help address decades-old questions such as apparent weakness of the SAF (Zoback, 2000) providing the unparalleled opportunity to constrain the parameters that control the behavior of plate bounding faults like the San Andreas.

Samples collected from SAFOD also complement studies of exhumed fault zones. While studies of exhumed fault zones have benefit from regionally extensive exposures that allow for detailed mapping and analyses (Chester and Chester, 1998; Evans and Chester, 1995), such studies also have inherent limitations including uncertainty about stress states and styles of deformation (i.e., seismogenic vs. creeping). Moreover, mineral assemblages in exhumed fault zones can be altered during exhumation, obscuring faultrelated mineral assemblages and textures (Solum et al., 2003; Solum and van der Pluijm, 2004).

The SAFOD target zone contains two parallel strands that generate repeating $\mathrm{M} 2$ earthquakes in addition to having a component of creep (Nadeau et al., 2004). Therefore, SAFOD also offers the opportunity to obtain samples from seismogenic and aseismic faults and to constrain the rheology of the active SAF system.

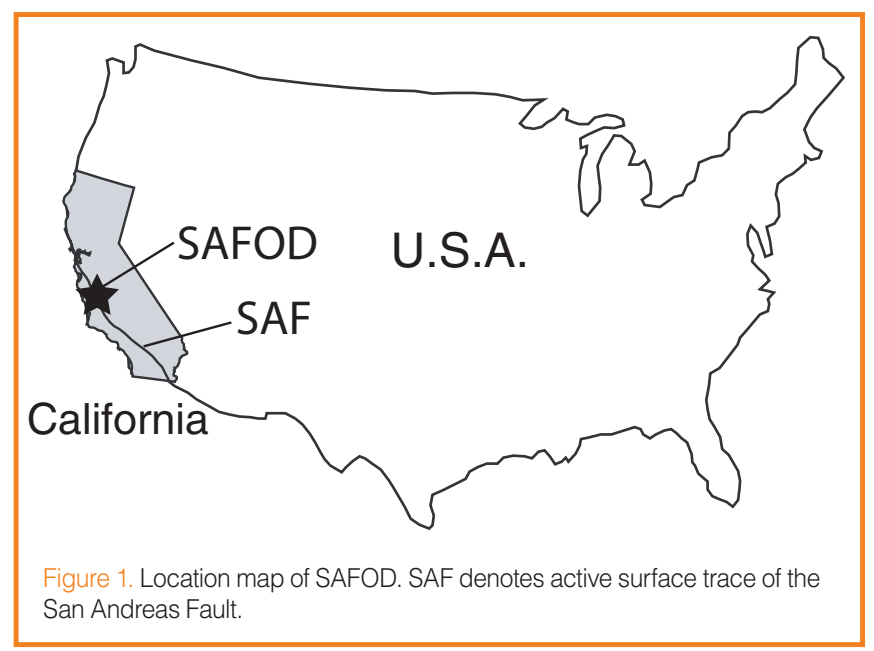

\section{Samples Collected}

Three types of samples were collected during drilling of the SAFOD main hole: rotary drill cuttings, spot cores, and percussive sidewall cores. A complete list of samples is available at: http://safod.icdp-online.org/.

The vast majority of samples collected to date are cuttings ( $>99 \%$ of the length of the hole). Two groups of rotary cuttings were collected at 3-m intervals over the entire length of the hole. One set was composed of unwashed cuttings (cuttings mixed with drilling mud collected as they come off the shale shaker), while the other was composed of washed cuttings, which are equivalent to unwashed cuttings that were gently rinsed on-site to remove drilling mud.

Three spot cores were collected following casing runsone in a hornblende-biotite granodiorite at 1462-1470 m measured depth (MD), one in an arkose/siltstone at the bottom of the Phase I hole at 3056-3067 m MD, and one at the bottom of the Phase II hole at 3990-3998 m MD. Fifty-two percussive side wall cores were collected from 3081-3953 m MD preceding casing of the Phase 2 hole in August 2005. Most of these samples were in siltstone/shale; however, two were in arkose.

Each type of sample has potential problems that must be addressed individually. For cuttings, these include loss of formation clays during on-site washing; difficulty resolving thin features like thin beds or faults (since cuttings represent an average over a 3-m-long interval); mixing as cuttings travel from the drill bit to the surface; contamination of cuttings derived at the drill bit by borehole collapses and abrades further up the hole; and contamination from materials from the drill string (e.g., steel shavings, paint) or from drilling additives (e.g., nut plug). Problems associated with side wall cores include disruption of natural textures and inducement of fractures during the collection process; contamination of the core from drilling mud (as the tool shoots through the borehole wall into the formation); and the potential that the core will sample the cuttings bed and not the formation. In addition, side wall cores can only be collected from regions of the hole that are relatively in gauge, which can eliminate the sampling weak areas such as fault zones, that are prone to washouts. Side wall cores also provide only a $2.5-\mathrm{cm}$ snapshot of lithology. Drilling mud 


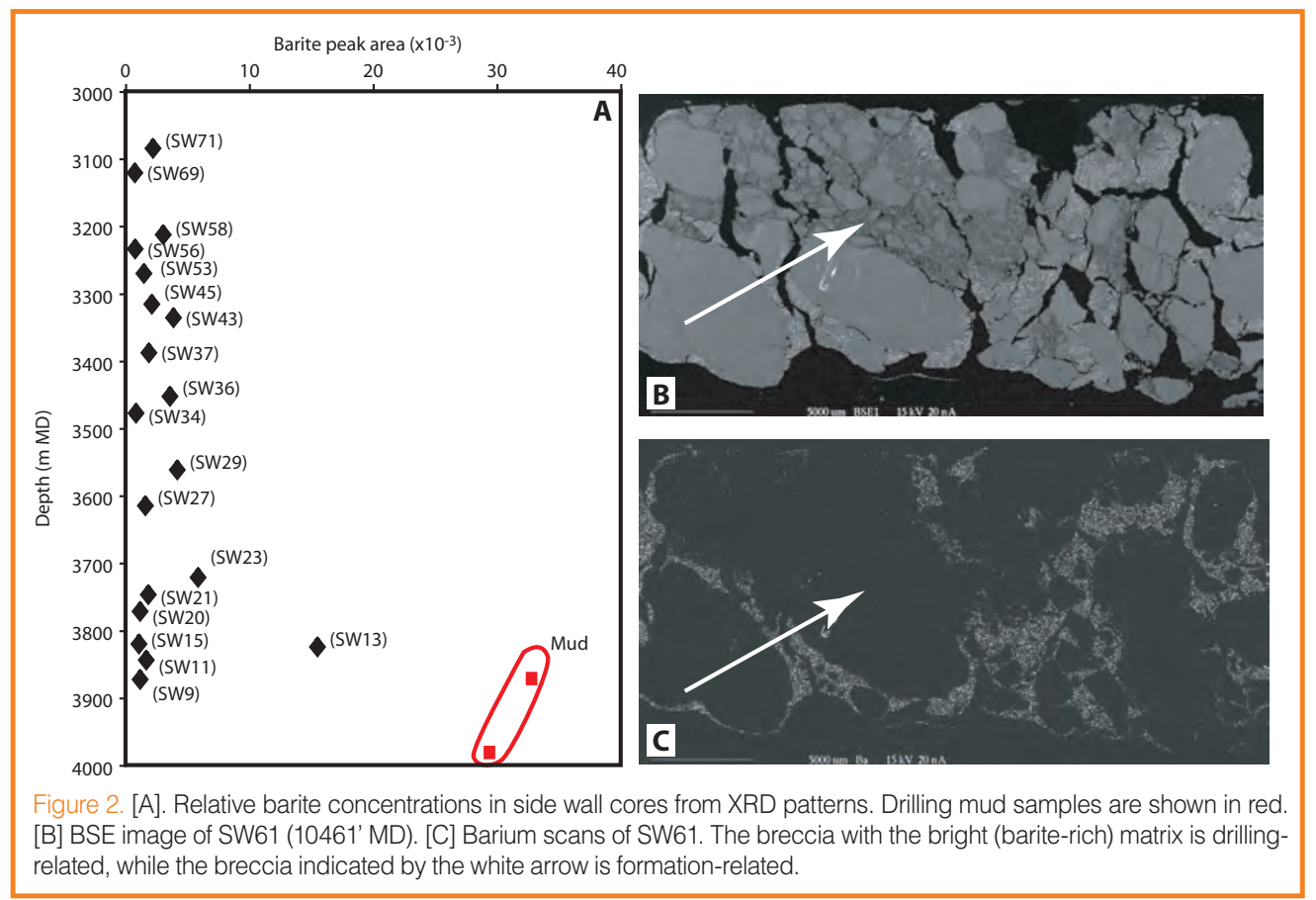

hole entered a series of mudrocks (Great Valley sequence) at $3158 \mathrm{~m} \mathrm{MD}$, which are separated from a mineralogically distinct series of Great Valley mudrocks by an actively creeping member of the SAF system that is causing casing deformation (Zoback et al., 2005). This formation extends to the bottom of the hole at $3998 \mathrm{~m}$ MD.

At least five major faults were crossed during drilling (Figs. 2 and 4), including an actively creeping member of the SAF system that is causing casing deformation at a depth of 3295-3313 m MD (Zoback et al., 2005). The creep occurs

contamination of side wall cores can be constrained using XRD and SEM (Fig. 2). SEM characterizations of the side wall cores allow textures that are drilling-induced to be distinguished from natural textures. Spot cores present fewer analytical difficulties than rotary cuttings or side wall cores; however, spot cores sampled less than $0.5 \%$ of the length of the SAFOD main hole. It is therefore vital to place spot and side wall cores into a broader geologic context, and this must be done using analyses of rotary cuttings (Fig. 3).

\section{Sample Mineralogies}

The mineral assemblages of samples were characterized using x-ray diffraction (XRD) (Solum et al., submitted), optical microscopy (Almeida et al., 2005; Barton et al., 2005; Draper et al., 2005; Evans et al., 2005), infrared reflectance (IR) (Calvin and Solum, 2005), scanning electron microscopy (SEM) (Hickman et al., 2005) and transmission electron microscopy (TEM) on select spot core samples (Schleicher et al., 2006). A summary of cuttings and core mineralogy is shown in Fig. 2.

Changes in mineralogy inferred from cuttings strongly correlate with geophysical logs (Solum et al., submitted), indicating that cuttings analyses reveal real lithologic boundaries and faults. These changes define mineralogical zones that are likely fault-bounded.

After penetrating the sedimentary cover, the hole entered Salinian granitic rocks. At $1926 \mathrm{~m}$ MD the hole crossed the Buzzard Canyon Fault (Rymer et al., 2003) and entered a series of arkosic sediments composed of an upper and a lower unit separated by a large fault at $\sim 2560 \mathrm{~m} \mathrm{MD} \mathrm{(Solum} \mathrm{et} \mathrm{al.,}$ submitted; Draper et al., in prep.), and containing a potentially active member of the SAF system at $3067 \mathrm{~m} \mathrm{MD}$. The within a low-velocity zone interpreted as the damage zone of the active SAF (Zoback et al., 2005). Between $3322 \mathrm{~m}$ and $3353 \mathrm{~m} \mathrm{MD}$, this zone contains up to $\sim 2 \mathrm{wt} \%$ serpentine, preliminarily identified as lizardite with minor chrysotile, based on crystal morphologies, (Solum et al., submitted); however, given the limitations inherent in the use of cuttings, the relationship of this serpentine to faulting cannot be definitively established until Phase III drilling in the summer of 2007. Two major faults, one at 2545-2560 m MD and one at $3067 \mathrm{~m} \mathrm{MD}$, are clay-rich (>50 wt\%) containing a neoformed mixed-layer clay (Solum et al., submitted; Schleicher et al., 2006). The Buzzard Canyon Fault at 1926-1235 m MD is rich in quartz and feldspars ( $>80 \mathrm{wt} \%)$ and contains relatively little clay $(<3 \mathrm{wt} \%)$. These preliminary results highlight the

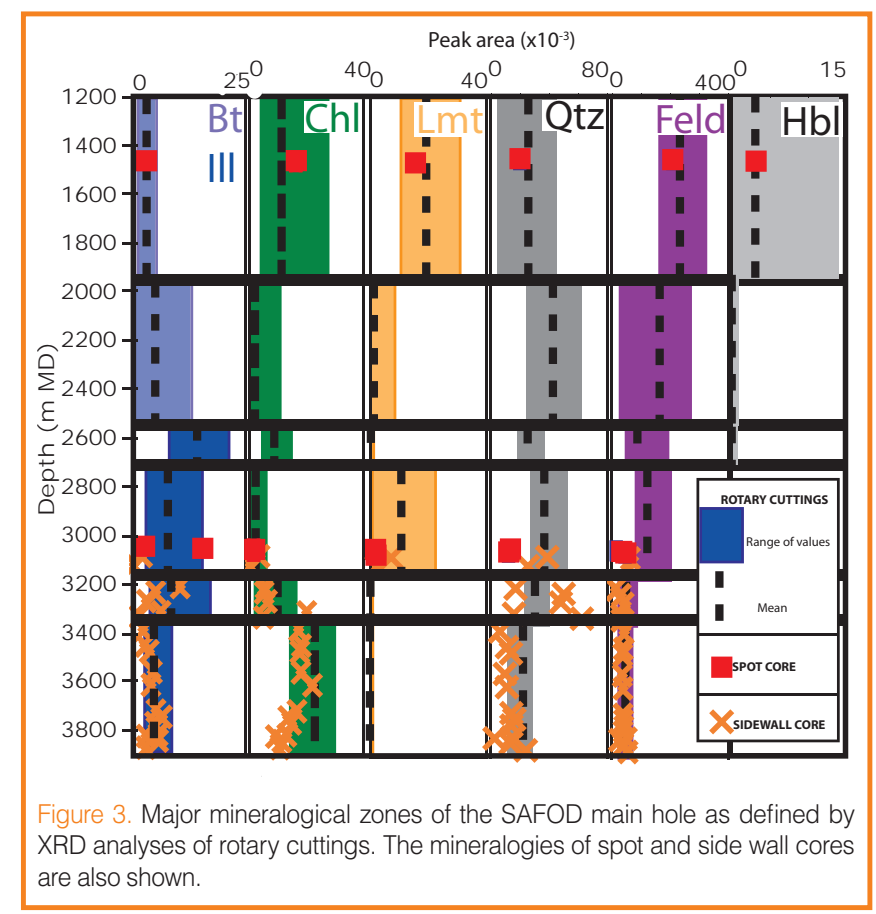




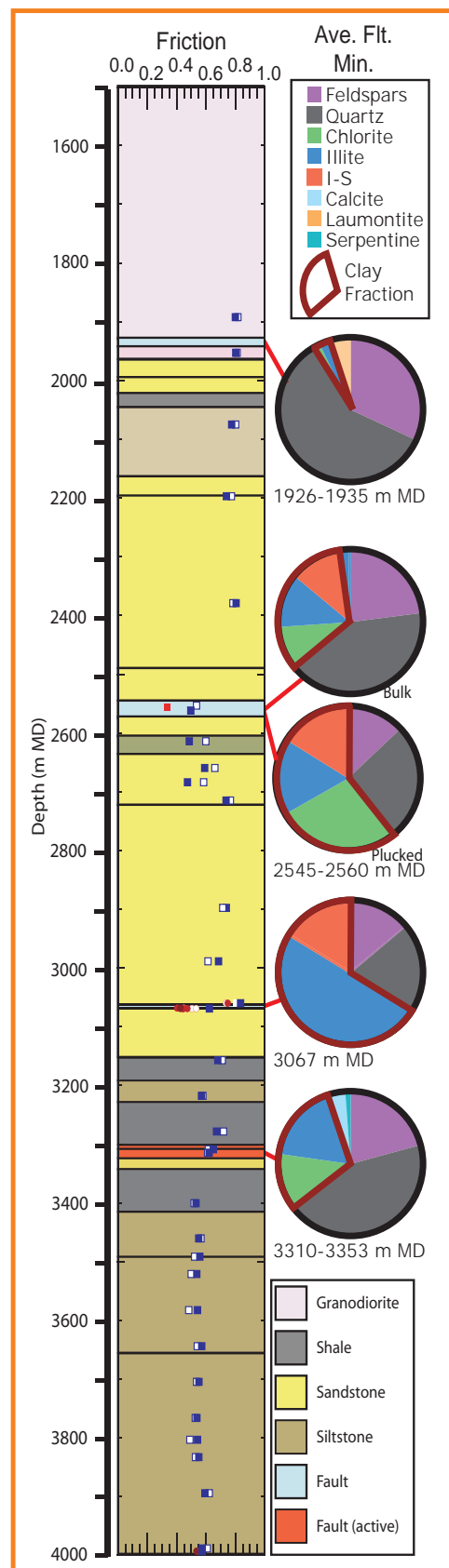

Figure 4. Coefficients of friction for samples from the SAFOD hole (Tembe et al., submitted). Average fault rock mineral assemblages are shown at right (Solum et al., in review). Lithologies are from Boness and Zoback (2006) compositional and rheological heterogeneity of the faults of the SAF system at SAFOD.

Alteration phases such as clays, zeolites, and some feldspars may record alteration by fluids that were confined by sealing faults. In addition, Kirschner et al. (2005) found that the stable isotopic composition of carbonates plucked from cuttings at $3100-$ $3950 \mathrm{~m}$ MD fell into two partially overlapping populations. One occurred more frequently in fault zones, while the other occurred more frequently in protolith. This suggests that in the region of SAFOD faults are tapping a fluid reservoir that is not seen in the protolith.

Constraining the frictional properties of the SAF is a key objective of SAFOD. Tembe et al. (2005) showed that cuttings preserve meaningful information about the frictional properties of the rocks penetrated during drilling, with faults generally weaker than adjacent protolith ( $\mu=0.40-0.55$ vs. $\mu=0.55-0.80$ ). Plucked grains of clay-rich fault rocks from $2556 \mathrm{~m}$ MD have $\mu=0.33$, while bulk samples from that depth have $\mu \approx 0.45$. This indicates that analyses of bulk samples provide an upper bound on the coefficient of friction, and that the properties of fault rocks can be better constrained by plucking grains of fault rocks from bulk cuttings. Analyses of plucked fault rocks from the section of the hole that contains the actively creeping fault are ongoing.

\section{Conclusions}

The ongoing studies briefly discussed here will help to increase the understanding of the behavior of the active SAF. Further, comprehensive studies of all of the faults penetrated during drilling of SAFOD provide the opportunity to constrain the rheological, structural, and geochemical evolution of this section of the SAF. Analyses of cuttings and Phase I and II cores define the broad geologic framework of the SAFOD area and will help guide the selection of targets for Phase III drilling in the summer of 2007.

\section{References}

Almeida, R., Chester, J.S., Chester, F.M., Kirschner, D.L., Waller, T.D., and Moore, D.E., 2005. Mesoscale structure and lithology of the SAFOD Phase 1 and II Core Samples. Eos Trans. AGU, 86(52), Fall Meet. Suppl., Abstract T21A-0454.

Barton, D., Bradbury, K.K., Solum, J.G., and Evans, J., 2005. Structural and lithologic characterization of the SAFOD pilot hole and phase one main hole. Eos Trans. AGU, 86(52), Fall Meet. Suppl., Abstract T21A-0451.

Boness, N.L. and Zoback, M.D., 2006. A multiscale study of the mechanisms controlling shear velocity anisotropy in the San Andreas Fault Observatory at Depth. Geophysics, 71:131-146, doi:10.1190/1.2231107.

Calvin, W.M. and Solum, J.G., 2005. Drill hole logging with infrared spectroscopy. Geothermal Resources Council Trans., 29:565568.

Chester, F.M. and Chester, J.S., 1998. Ultracataclasite structure and friction processes of the Punchbowl fault, San Andreas system, California. Tectonophysics, 295:199-221, doi:10.1016/ S0040-1951(98)00121-8.

Draper, S.A., Boness, N.L., and Evans, J.P., 2005. Source and significance of the sedimentary rocks in the SAFOD borehole: Preliminary analysis, Eos Trans. AGU, 86(52), Fall Meet. Suppl., Abstract T24B-02.

Evans, J., Moore, D., Kirschner, D., and Solum, J.G., 2005. Lithologic characterization of the deep portion of the SAFOD drill hole. Eos Trans. AGU, 86(52), Fall Meet. Suppl., Abstract T21A-0450.

Evans, J.P. and Chester, F.M., 1995. Fluid-rock interaction in faults of the San Andreas system; inferences from San Gabriel Fault rock geochemistry and microstructures. J. Geophys. Res., 100:13007-13020, doi:10.1029/94JB02625.

Hickman, S., Solum, J., Moore, D., Chester, J., Guillemette, R., Draper, S., Tembe, S., Boness, N., and Summers, R., 2005. Photographs and scans of SAFOD phase 2 sidewall sores, SAFOD phase 2 sample party, Menlo Park, Calif., U.S.A., http://geoweb.tamu.edu/Faculty/chesterj/safod/ products/Phase_2_Sidewall_Cores.ppt

Hickman, S., Zoback, M., and Ellsworth, W., 2004. Introduction to special section: Preparing for the San Andreas Fault Observatory at Depth. Geophys. Res. Lett., 31:L12S01, doi:10.1029/2004GL020688. 
Kirschner, D., Evans, J., Chester, J., Chester, F., Solum, J.G., and Moore, D.E., 2005. Elemental and stable isotope chemistry of cuttings and core samples from SAFOD drill hole. Eos Trans. AGU, 86(52), Fall Meet. Suppl., Abstract T21A-0452.

Nadeau, R.M., Michelini, A., Urhammer, R.A., Dolenc, D., and McEvilly, T.V., 2004. Detailed kinematics, structure and recurrence of microseismicity in the SAFOD target region. Geophys. Res. Lett., 31:L12S08, doi:10.1029/2003GL019409.

Rymer, M.J., Catchings, R.D., and Goldman, M.R., 2003. Structure of the San Andreas Fault zone as revealed by surface geologic mapping and high-resolution seismic profiling near Parkfield, California. Geophys. Res. Abs., 5:13523.

Schleicher, A.M., van der Pluijm, B.A., Solum, J.G., and Warr, L.N., 2006. The origin and significance of clay minerals on surfaces, in fractures and in veins from SAFOD borehole samples (Parkfield, California). Geophys. Res. Lett., 33: L16313, doi:10.1029/2006GL026505.

Solum, J.G. and van der Pluijm, B.A., 2004. Phyllosilicate mineral assemblages of the SAFOD Pilot Hole and comparison with an exhumed segment of the San Andreas Fault System. Geophys. Res. Lett., 31:L15S19, doi:10.1029/2004GL01990.

Solum, J.G., Hickman, S.H., Lockner, D.A., Moore, D.E., van der Pluijm, B.A., Schleicher, A.M., and Evans, J.P., 2006. Mineralogical characterization of protolith and fault rocks from the SAFOD main hole. Geophys. Res. Lett., 33:L21314, doi:10.1029/2006GL027285.

Solum, J.G., van der Pluijm, B.A., Peacor, D.R., and Warr, L.N., 2003. The influence of phyllosilicate mineral assemblages, fabrics, and fluids on the behavior of the Punchbowl Fault, southern California. J. Geophys. Res., 108:2233, doi:10.1029/ 2002JB001858.

Tembe, S., Lockner, D.A., Solum, J.G., Morrow, C., Wong, T.-f., and Moore, D.E., 2005. Frictional strength of the San Andreas fault zone: Insight from SAFOD cuttings and core. Eos Trans. AGU, 86(52), Fall Meet. Suppl., Abstract T24B-03.

Zoback, M.D., Hickman, S., and Ellsworth, W., 2005. Overview of SAFOD Phases 1 and 2: Drilling, sampling and measurements in the San Andreas Fault zone at seismogenic depth. Eos Trans. AGU, 86(52), Fall Meet. Suppl., Abstract T23E01.

Zoback, M.D., 2000. Strength of the San Andreas fault. Nature, 405:31-32.

\section{Related Web Links}

http://www.earthscope.org

http://safod.icdp-online.org

\section{Authors}

John G. Solum, U.S. Geological Survey, Earthquake Hazards Team, 345 Middlefield Road, Mail Stop 977, Menlo Park, Calif., U.S.A., (currently) Sam Houston State University, Department of Geography and Geology, Huntsville, Texas 77341, U.S.A., e-mail: jsolum@usgs.gov.

Stephen Hickman, U.S. Geological Survey, Earthquake Hazards Team, 345 Middlefield Road, Mail Stop 977, Menlo Park, Calif., U.S.A.
David. A. Lockner, U.S. Geological Survey, Earthquake Hazards Team, 345 Middlefield Road, Mail Stop 977, Menlo Park, Calif., U.S.A.

Sheryl Tembe, Department of Geosciences, 255 Earth and Space Sciences Building (ESS), Stony Brook University, Stony Brook N.Y. 11794-2100, U.S.A.

Jim P. Evans, Department of Geology, Utah State University, Logan, Utah 84322-4505, U.S.A.

Sarah D. Draper, Department of Geology, Utah State University, Logan, Utah 84322-4505, U.S.A.

D.C. Barton, Department of Geology, Utah State University, Logan, Utah 84322-4505, U.S.A.

David L. Kirschner, Department of Earth and Atmospheric Sciences, Saint Louis University, Verhaegen Hall, 3634 Lindell Boulevard, Suite 117, St. Louis, Mo. 63103, U.S.A.

Judith S. Chester, Room 228, Department of Geology and Geophysics, Texas A\&M University, College Station, Texas 77843-3115, U.S.A.

Frederick M. Chester, Department of Geology and Geophysics, M.T. Halbouty Building, Room 153, Texas A\&M University, College Station, Texas 77843-3115, U.S.A.

Ben A. van der Pluijm, Department of Geological Sciences, University of Michigan, 4534B C.C. Little Building, 1100 North University Avenue, Ann Arbor, Mich. 48109-1005, U.S.A.

Anja M. Schleicher, Department of Geological Sciences, University of Michigan, 2534 C.C. Little Building, 1100 North University Avenue, Ann Arbor, Mich. 48109-1005, U.S.A.

Diane E. Moore, U.S. Geological Survey, Earthquake Hazards Team, 345 Middlefield Road, Mail Stop 977, Menlo Park, Calif., U.S.A.

Carolyn Morrow, U.S. Geological Survey, Earthquake Hazards Team, 345 Middlefield Road, Mail Stop 977, Menlo Park, Calif., U.S.A.

Kelly Bradbury, Department of Geology, Utah State University, Logan, Utah 84322-4505, U.S.A.

Wendy M. Calvin, Department of Geological Sciences, University of Michigan, 4534B C.C. Little Building, 1100 North University Avenue, Ann Arbor, Mich. 48109-1005, U.S.A., (currently) Department of Geology and Engineering, Mail Stop 172, University of Nevada, Reno, 1664 North Virginia Street, Reno, Nev. 89557-0138, U.S.A.

Teng-fong Wong, Department of Geosciences, 255 Earth and Space Sciences Building (ESS), Stony Brook University, Stony Brook N.Y. 11794-2100, U.S.A. 